\title{
HUBUNGAN ANTARA PENGETAHUAN DAN SIKAP TERHADAP PEMERIKSAAN VCT HIV PADA WANITA PEKERJA SEKS DIWILAYAH KERJA PUSKESMAS DUREN BANDUNGAN
}

\author{
Putri Rahma Dini ${ }^{1)}$, Lista Irna ${ }^{2)}$ \\ ${ }^{1}$ Program Studi Sarjana Terapan Kebidanan, STIKES Karya Husada Semarang \\ ${ }^{2}$ Program Studi Kebidanan, STIKES Ngudi Waluyo Ungaran \\ Email: putrirahmadini91@gmail.com
}

\begin{abstract}
ABSTRAK
Layanan kesehatan yang pertama dalam pencegahan penularan HIV (Human Immunodeficiency Virus) adalah layanan VCT (Voluntary Counseling and Testing). Pendidikan kesehatan tentang HIV/AIDS merupakan kebutuhan di Indonesia. Sikap positif kecenderungan tindakan adalah mendukung dalam pemeriksaan VCT. Jenis penelitian ini adalah survey analitik dengan pendekatan cross-sectiona. Populasi penelitian ini adalah wanita pekerja seks di wilayah kerja puskesmas Duren Bandungan dengan jumlah sampel 72, dengan menggunakan teknik sampling random. Alat pengumpul data dalam penelitian ini menggunakan kuesioner pengetahuan HIV/AIDS dan sikap terhadap pemeriksaan VCT HIV pada wanita pekerja seks. Uji analisis data menggunakan fisher exact. Hasil penelitian menunjukkan bahwa mayoritas pada kategori pengetahuan baik sebesar 73,6 \%, sikap positif sebesar 77,8 \%. Uji statistik didapatkan hasil ada hubungan yang bermakna antara pengetahuan dan sikap terhadap pemeriksaan VCT HIV pada wanita pekerja seks di wilayah kerja Puskesmas Duren Bandungan $(\mathrm{p}$ value $=0,001)<\alpha(0,05)$.
\end{abstract}

Kata Kunci: pengetahuan, sikap, HIV/AIDS, VCT

\begin{abstract}
The first health care in preventing Human Immunodeficiency Virus (HIV) transmission is Voluntary Counseling Testing (VCT) services. Health education about HIV is important in Indonesia. A positive attitude is the action to support Voluntary Counseling Testing examination. The type of the research was analytical survey with cross-sectional. This study population was female prostitutes in the region of Duren health center Bandungan with the samples of 72, people by using random sampling technique. The tool of data collecting in this study used questionnaires about knowledge of HIV / AIDS and attitude toward HIV / VCT screening on female prostitutes. In testing the correlation between variables used fisher exact test. The results showed that the majority of the respondents had good knowledge of 73,6 \%, and positive attitude of 77,8 \%. Statistical test showed a significant correlation between the knowledge about HIV AIDS and attitude about VCT screening in female prostitutes at the area $(p$ value $=0.001)<\alpha(0,05$.
\end{abstract}

Keywords: knowledge, attitude, HIV AIDS, VCT 


\section{PENDAHULUAN}

HIV (Human Immunodeficiency Virus) yaitu virus yang menyerang sistem kekebalan tubuh manusia. Virus HIV akan masuk dalam sel darah putih dan merusaknya, sehingga sel darah putih yang berfungsi sebagai pertahanan terhadap infeksi akan menurun jumlahnya. Akibatnya sistem kekebalan tubuh menjadi lemah dan penderita mudah terkena berbagai penyakit. AIDS (Acquired Immuno Deficiency Syndrom) yaitu kumpulan gejala penyakit (sindrom) yang didapat akibat turunnya kekebalan tubuh yang disebabkan oleh HIV (Kumalasari, 2012).

Berdasarkan data statistic pengidap HIV/AIDS di dunia, lebih dari 35 juta orang sekarang hidup dengan HIV/AIDS (UNAIDS, 2013). Kasus AIDS pertama kali dilaporkan di USA tahun 1981 dan dalam kurun waktu 10 tahun telah menyebar hampir ke seluruh dunia. Lebih dari 150 negara di dunia telah melaporkan adanya penyakit infeksi HIV/AIDS. Di Afrika khusunya Sub-Sahara, 30 juta jiwa penduduknya mengidap HIV dan lebih 10 juta jiwa terinfeksi baru setiap tahunnya. Situasi senada terjadi di Uganda, negara berpenduduk 20 juta tersebut 2 juta di antaranya diserang HIV/AIDS, 300-400 kematian akibat AIDS terjadi setiap hari (Nasronudin, 2012).

Layanan kesehatan yang pertama dalam pencegahan penularan HIV adalah layanan VCT (Voluntary Counseling and Testing). VCT merupakan komponen penting dalam pemberantasan HIV, yang meliputi upaya pencegahan, perawatan dan pengobatan. Dalam upaya meningkatkan pencegahan dan pengobatan, peningkatan konseling dan tes HIV sangat diperlukan. Secara global masyarakat yang melakukan tes HIV sampai saat ini masih rendah (Obermeyer and Osborn, 2007).

Pekerja seks sebesar 14\% yang dapat mengakses pelayanan VCT. Sebesar $24 \%$ pekerja seks perempuan yang bias mengidentifikasi secara benar cara-cara pencegahan penularan HIV secara seksual. Perilaku berisiko juga masih banyak dilakukan, antara lain hanya sekitar $50 \%$ pekerja seks perempuan dan lelaki suka lelaki yang melaporkan secara rutin menggunakan kondom (KPAN, 2010).

Salah satu kelompok risiko tinggi adalah wanita pekerja seks (WPS). Faktor yang menyebabkan kasus HIV/AIDS terus melonjak, disebabkan karena adanya perilaku menyimpang dari perilaku wanita pekerja seks (WPS), homoseks, dan pengguna narkoba suntik yang saling bergantian (Adisasmito, 2010).

Pendidikan kesehatan tentang HIV/AIDS merupakan kebutuhan yang mendesak di Indonesia. Hal ini didasarkan pada data $85 \%$ WPS di Indonesia bekerja di luar lokalisasi dan tidak pernah menggunakan kondom dalam hubungan seksual dengan klien (UNAIDS, 2004). Pendidikan kesehatan menjadi salah satu usaha peningkatan pengetahuan, di mana pengetahuan merupakan salah satu komponen yang penting dalam prevensi HIV/AIDS (Santos-Ortiz, 2004).

Sikap merupakan proses kesadaran yang menentukan tindakan nyata dan yang mungkin dilakukan individu dalam kehidupan sosialnya. Sebagai hasil evaluasi, sikap yang disimpulkan dari berbagai pengamatan terhadap objek diekspresikan dalam bentuk respon kognitif, efektif maupun perilaku (Wawan \& Dewi, 2010).

Sikap dapat dipengaruhi oleh banyak hal, selain dari faktor pengetahuan juga dipengaruhi oleh faktor kebudayaan, orang lain yang dianggap penting, media massa, pengalaman pribadi, lembaga pendidikan, lembaga agama dan emosi dari dalam individu. Sikap terhadap pemeriksaan VCT pada WPS bisa berwujud positif ataupun negatif, sikap positif kecenderungan tindakan adalah mendukung dalam pemeriksaan VCT pada WPS sedangkan sikap negatif kecenderungan tindakannya adalah menghindari pemeriksaan VCT (Azwar, 2009).

Pengetahuan adalah merupakan hasil dari tahu dan ini terjadi setelah seseorang melakukan penginderaan terhadap suatu objek tertentu. Wawan (2010) mengemukakan bahwa salah satu faktor yang dapat mempengaruhi sikap adalah pengetahuan. Sehingga diharapkan pengetahuan yang baik akan menunjang terhadap sikap dalam pemeriksaan VCT. Pengetahuan tentang HIV/AIDS dapat mempengaruhi sikap individu tersebut terhadap pemeriksaan VCT (Wawan, 2010).

Berdasarkan data yang didapatkan dari staf Puskesmas Duren Bandungan Kabupaten Semarang tahun 2015, didapatkan informasi bahwa jumlah WPS yaitu sebanyak 250 orang, dari 250 orang dan terdapat 5 orang positif mengidap HIV/AIDS. Di Puskesmas Duren memberikan pelayanan VCT kepada WPS, dalam melakukan pemeriksaan VCT dilakukan $1 \mathrm{x}$ dalam 3bulan. Setiap jadwal kunjungan jumlah WPS yang periksa tidak tentu, kadang mengalami peningkatan dan penurunan.

Berdasarkan hasil studi pendahuluan di Puskesmas Duren Bandungan yang didapatkan melalui pengisian kuesioner dengan 10 pertanyaan pengetahuan tentang HIV/AIDS dan 2 pertanyaan tentang sikap terhadap pemeriksaan VCT, didapatkan informasi bahwa dari 7 WPS, terdapat 3 WPS yang memiliki pengetahuan kurang dan 4 WPS memiliki pengetahuan baik. Dari 4 WPS yang memiliki pengetahuan baik terdapat 3 WPS yang memiliki sikap baik terhadap pemeriksaan VCT 
dan 1 WPS memiliki sikap kurang baik terhadap pemeriksaan VCT, Sedangkan 3 WPS yang memiliki pengetahuan kurang terdapat 2 WPS yang memiliki sikap kurang terhadap pemeriksaan VCT, dan 1 WPS memiliki sikap yang baik terhadap pemeriksaan WPS.

Berdasarkan latar belakang diatas maka dapat diangkat permasalahan dalam penelitian ini adalah " Adakah hubungan antara pengetahuan dan sikap terhadap pemeriksaan VCT HIV pada wanita pekerja seks di wilayah kerja Puskesmas Duren Bandungan".

\section{METODE}

Desain yang digunakan dalam penelitian adalah survey analitik. Desain ini digunakan karena peneliti mencoba menggali bagaimana dan mengapa fenomena itu bisa terjadi. Kemudian melakukan analisis dinamika korelasi antara fenomena, baik antara faktor resiko dengan faktor efek. Desain survai analatik ini digunakan untuk mengukur hubungan korelasi antara pengetahuan dan sikap terhadap pemeriksaan VCT HIV.

Tabel 1. Hubungan antara pengetahuan dan sikap terhadap pemeriksaan VCT HIV pada wanita pekerja seks di wilayah kerja Puskesmas Duren Bandungan

\begin{tabular}{cccccccc}
\hline \multirow{2}{*}{ Pengetahuan } & \multicolumn{4}{c}{ Sikap } & \multicolumn{2}{c}{ Total } & \multirow{2}{*}{ p value } \\
\cline { 2 - 6 } & \multicolumn{2}{c}{ Negatif } & \multicolumn{2}{c}{ Positif } & \multirow{2}{*}{ F } & $\%$ & \\
\cline { 2 - 7 } & $\mathrm{F}$ & $\%$ & $\mathrm{~F}$ & $\%$ & & \\
\hline Cukup & 10 & $52,6 \%$ & 9 & $47,4 \%$ & 19 & $100 \%$ & 0,001 \\
\hline Baik & 6 & $11,3 \%$ & 47 & $88,7 \%$ & 53 & $100 \%$ & Ha diterima \\
\hline Total & 16 & $22,2 \%$ & 56 & $77,8 \%$ & 72 & $100 \%$ &
\end{tabular}

Berdasarkan uji statistik fisher exact diketahui $\mathrm{p}$ value $0,001<\alpha(0,05)$, dapat disimpulkan bahwa Ha diterima, berarti ada hubungan bermakna antara pengetahuan dan sikap terhadap pemeriksaan VCT HIV pada wanita pekerja seks di wilayah kerja Puskesmas Duren Bandungan.

\section{PEMBAHASAN}

Hubungan antara pengetahuan dan sikap terhadap pemeriksaan VCT HIV pada wanita pekerja seks di wilayah kerja Puskesmas Duren Bandungan

Hasil penelitian ini diketahui bahwa responden yang memiliki pengetahuan cukup, sebagian besar memiliki sikap negatif $10 \quad(52,6 \%)$ dikarenakan responden malas untuk melakukan pemeriksaan VCT karena belum memahami benar kegunaan tes HIV. Dan dapat diketahui bahwa responden yang memiliki pengetahuan cukup, sebagian besar memiliki sikap negatif dikarenakan responden kurang percaya pemeriksaan VCT bertujuan untuk pencegahan HIV/AIDS dan kurang mendapatkan informasiinformasi tentang kesehatan.

Pengetahuan itu sendiri dipengaruhi oleh faktor pendidikan formal. Pengetahuan sangat erat
Pendekatan penelitian menggunakan pendekatan crossectional, dimana subjek hanya diobservasi sekali saja dan pengukuran terhadap variabel dilakukan pada saat penelitian dalam suatu waktu (Notoatmodjo, 2010).

Populasi dalam penelitian ini adalah seluruh WPS yang berada di wilayah kerja Puskesmas Duren Bandungan dengan jumlah keseluruhan 250 orang. Sampel adalah bagian dari jumlah dan karakteristik yang dimiliki oleh populasi (Sugiyono, 2007). Sampel yang di ambil sejumlah 72 WPS. Tehnik pengambilan sampel yang digunakan peneliti yaitu random sampling, yang tehnik pengambilan sampel dengan cara acak tanpa memperhatikan strata yang ada dalam anggota populasi (Notoatmojdo, 2003).

Alat yang di gunakan untuk mengumpulkan data yaitu kuesinoner yang berbentuk 13 pernyataan untuk mengetahui pengetahuan dan 12 kuesioner untuk mengetahui sikap terhadap pemeriksaan VCT HIV

\section{HASIL}

hubungannya dengan pendidikan, dimana diharapkan bahwa dengan pendidikan yang tinggi maka orang tersebut akan semakin luas pula pengetahuannya. Akan tetapi perlu ditekankan, bukan berarti seseorang yang berpendidikan rendah mutlak berpengetahuan rendah pula. Hal ini mengingat bahwa peningkatan pengetahuan tidak mutlak diperoleh melalui dari pendidikan non formal saja, akan tetapi dapat diperoleh melalui pendidikan non formal. Pengetahuan seseorang tentang suatu objek mengandung dua aspek yaitu aspek positif dan aspek negatif. Kedua aspek ini yang akan menentukan sikap seseorang, semakin banyak aspek positif dan objek yang diketahui, maka akan menimbulkan sikap makin positif terhadap objek tertentu (Wawan \& Dewi, 2010).

Sikap merupakan proses kesadaran yang menentukan tindakan nyata dan yang mungkin dilakukan individu dalam kehidupan sosialnya. Sebagai hasil evaluasi, sikap yang disimpulkan dari berbagai pengamatan terhadap objek diekspresikan dalam bentuk respon kognitif, efektif maupun perilaku (Wawan \& Dewi, 2010). 
Kurangnya pengetahuan disebabkan oleh kurang terpapar informasi yang dapat menyebabkan terjadinya penularan infeksi HIV/AIDS secara tidak langsung, hal ini disebabkan kurangnya pengetahuan dapat menyebabkan individu salah dalam bersikap dan berperilaku. Faktor sosial berkaitan dengan kemampuan masyarakat mendapatkan sumbersumber informasi baik formal maupun informal. Kurangnya paparan terhadap informasi khususnya masalah kesehatan berpengaruh diterhadap sikap dan perilaku, sehingga cenderung melakukan tindakan yang berisiko terhadap masalah kesehatan (Setyoadi, 2012).

Hasil penelitian ini sejalan dengan pendapat Notoatmodjo, (2003) bahwa pengetahuan atau kognitif merupakan domain yang sangat penting dalam bentuk tindakan seseorang (overt behavior), karena dari pengalaman dan penelitian terbukti bahwa perilaku yang didasari oleh pengetahuan akan lebih langgeng dari pada perilaku yang tidak didasari oleh pengetahuan.

Hasil penelitian ini diketahui bahwa responden yang memiliki pengetahuan cukup, sebagian besar bersikap positif $9(47,4 \%)$ dikarenakan responden yakin adanya pemeriksaan VCT dapat mengurangi kegelisahan dan meningkatkan persepsi mereka terhadap gejala dan penularan HIV itu terjadi. Dapat disimpulkan bahwa pengetahuan cukup mempengaruhi sikap mereka untuk melakukan pemeriksaan HIV VCT. Responden yang mempunyai pengetahuan cukup pasti mempunyai sikap cukup pula. Hal ini dapat dilihat bahwa responden dalam menentukan sikap tergantung dari pengaruh orang lain yaitu tergantung dari pengetahuan yang telah mereka terima.

Hasil penelitian ini sejalan dengan pendapat Azwar S (2009) bahwa komponen kognitif menunjang terbentuknya sikap. Komponen kognitif merupakan representasi apa yang dipercayai oleh individu pemilik sikap, komponen kognitif berisi kepercayaan stereotipe yang dimiliki individu mengenai sesuatu dapat disamakan penanganan (opini) terutama apabila menyangkut masalah isu atau problem yang kontroversial.

Hasil penelitian ini diketahui bahwa responden yang memiliki pengetahuan baik, sebagian besar bersikap negatif $6(11,3 \%)$ dikarenakan responden kurang tahu pemeriksaan VCT bertujuan untuk pencegahan HIV/AIDS. Sehingga saat memberikan penyuluhan terhadap WPS, hendaknya pemberian informasi dilakukan secara individual agar tepat pada sasaran didik sehingga sumber informasi yang diperoleh dapat menumbuhkan dan mengembangkan suatu sikap pada diri pekerja seks komersial.

Struktur sikap menurut Azwar S., (2009) terdiri atas 3 komponen yang saling menunjang yaitu komponen kognitif, afektif, dan konatif. Komponen kognitif merupakan representasi apa yang dipercayai oleh individu pemilik sikap, komponen kognitif berisi kepercayaan stereotipe yang dimiliki individu mengenai sesuatu dapat disamakan penanganan (opini) terutama apabila menyangkut masalah isu atau problem yang kontroversial. Komponen afektif merupakan perasaan yang menyangkut aspek emosional. Aspek emosional inilah yang biasanya berakar paling dalam sebagai komponen sikap dan merupakan aspek yang paling bertahan terhadap pengaruh-pengaruh yang mungkin adalah mengubah sikap seseorang komponen afektif disamakan dengan perasaan yang dimiliki seseorang terhadap sesuatu. Komponen konatif merupakan aspek kecenderungan berperilaku tertentu sesuai dengan sikap yang dimiliki oleh seseorang. Dan berisi tendensi atau kecenderungan untuk bertindak/ bereaksi terhadap sesuatu dengan cara-cara tertentu. Dan berkaitan dengan objek yang dihadapinya adalah logis untuk mengharapkan bahwa sikap seseorang adalah dicerminkan dalam bentuk tendensi perilaku.

Hasil penelitian ini diketahui bahwa responden yang memiliki pengetahuan baik sebagian memiliki sikap positif $47(88,7 \%)$ dikarenakan responden percaya pemeriksaan VCT bertujuan untuk mencegah penularan HIV dan mereka paham tentang penularan HIV/AIDS yang sangat berbahaya bagi pekerja seks. Menurut keterangan dari responden mereka banyak mendapatkan informasi - informasi ataupun penyuluhan mengenai berbagai macam penyakit menular seksual dari media cetak, media elektronik dan dari berbagai penyuluhan LSM.

Pengembangan pengetahuan infeksi HIV/AIDS perlu dimulai dari pemahaman mendasar. Pengetahuan tentang infeksi HIV/AIDS perlu disosialisasikan ke masyarakat dengan memperhatikan dan ke masyarakat dengan memperhatikan menyesuaikan karakteristik masyarakat. Pemahaman secara mendasar tentunya tidak terlepas dari alur berfikir filosofis yang bearti berfikir untuk menemukan kebenaran secara seksama.Sehubungan dengan perkembangan pengetahuan penyakit infeksi HIV/AIDS, maka diperlukan adanya penentuan berbagai nilai yang patut mendapat perhatian kita sekarang ini (Nasronudin, 2012).

\section{SIMPULAN DAN SARAN Simpulan}


Berdasarkan dari 72 responden, sebagian besar pengetahuan baik sebesar 73,6 \% dan sebagian besar sikap positif sebesar $77,8 \%$. Sehingga dapat disimpulkan ada hubungan bermakna antara pengetahuan dan sikap terhadap pemeriksaan VCT HIV pada wanita pekerja seks di wilayah kerja Puskesmas Duren Bandungan ( $\mathrm{p}$ value : $0,001<0,05$ ).

\section{Saran}

Peningkatan pengetahuan pekerja seks komersial terhadap pencegahan penularan HIV/AIDS harus selalu dilakukan untuk mengurangi dan mencegah penyebaran virus HIV serta penyakit AIDS. Selain itu menganjurkan untuk selalu menggunakan kondom saat melakukan hubungan seksual dan juga rutin untuk melakukan VCT

\section{DAFTAR PUSTAKA}

Arikunto, S. 2010. Prosedur Penelitian. Jakarta : Rineka Cipta.

Arikunto, S. 2006. Penelitian dan Tindakan Kelas. Jakarta: Bumi Aksara.

Azwar, S. 2009. Sikap Manusia Teori dan Pengukurannya. Yogyakarta: Pustaka Pelajar Offset.

Ditjen PP \& PL Kemenkes RI. 2014. Laporan Kemenkes.

http://www.spiritia.or.id/Stats/StatCurr. php?lang=id\&gg=1 diakses pada tanggal 11 maret 2014.

Dinkes. 2013. Hingga Agustus 2013, Enam Pengidap HIV/AIDS di Semarang Tewas.

http://www.jatengtime.com/2013/semar angtoday/hingga-agustus-2013-enampengidap-hivaids-di-semarang-tewas/ diakses pada tanggal 28 maret.

Elisabet. 2013. Komitmen Dana AIDS. http://m.suaramerdeka.com/index.php/r ead/cetak/2013/12/05/245283 diakses pada tanggal 13 maret 2014.

Fahmi, P. 2012. Pelayanan VCT (Voluntary Conseling and Testing).

Family Health International (FHI). 2004. HIV Voluntary Counseling and Testing: A Reference Guide for Counselors and Trainers.

Gunarsa S. 2000. Konseling dan Psikologi. Jakarta: BPK Gunung Mulia.

Haruddin, Hasanbasri, M. Woerjandari, A. 2007. Studi pelaksanaan HIV Voluntary Counseling And Testing (VCT) di
RSUP Dr. Sardjito Yogyakarta. Working Paper Series No. 3, Program Magister Kebijakan dan Manajemen Pelayanan Kesehatan. Universitas Gadjah Mada, Yogyakarta.

Hidayat,A.A. 2007. Metode Penelitian Keperawatan dan Teknik Analisis Data, Jakarta : Salemba Medika.

Hutapea, R. (2011). AIDS \& PMS dan Perkosaan. Jakarta : Rineka Cipta.

Indiyani. (2013). Sejarah HIV/AIDS. http://gaulfresh.com/sejarah-

hivaids.html diakses pada tanggal 13 maret 2014.

Komisi Penanggulangan AIDS. 2010. Strategi Nasional Penaggulangan HIV dan AIDS 2010-2014. Kumalasari, I., \& Andhyantoro, I. 2012. Kesehatan Reproduksi untuk Mahasiswa Kebidanan dan Keperawatan. Jakarta: Salemba Medika.

Matyunani , A. 2009. Pencegahan Penularan HIV dari Ibu Ke Bayi: Penatalaksaan Di Pelayanan Kebidanan. Jakarta: TIM.

Nasronudin. 2012. HIV \& AIDS Pendekatan Biologi Molekuler, Klinis dan Sosial. Surabaya: Pusat Penerbitan dan Percetakan Unair.

Notoatmodjo, S. 2003. Ilmu Kesehatan Masyarakat (Prinsip-Prinsip Dasar), Jakarta : PT, Rineka Cipta.

Notoatmodjo, S. 2007. Promosi Kesehatan dan Ilmu Perilaku, Jakarta : Rineka Cipta.

Notoatmodjo, S. 2010. Metodelogi Penelitian Kesehatan. Jakarta: PT. Renika Cipta.

Nursalam, \& Ninuk, D.K. 2011. Asuhan Keperawatan pada Pasien Terinfeksi HIV/AIDS. Jakarta: Salemba Medika.

Pelayanan VCT Voluntary Counseling Testing. Sabtu, 22 Desember 2012. http://rfahmi-p-

fkm11.web.unair.ac.id/artikel_detail69750-Kesehatan-

Pelayanan\%20VCT\%20\%28Voluntary $\%$ 20Counseling\%20and\%20Testing\%2 9.html diakses pada tanggal 30 November 2013. 
Santos-Ortiz. Hernando Mattei. Kenja Correa-

Nivar. Elizabeth Pintado-Díaz. 2004.

HIV/AIDS Among Middle and Older

Adults in Puerto

Rico.http://www.hawaii.eduhivandaids

HIVAIDS_Among_Middle_and_Older

_Adults_in_Puerto_Rico.pdf . diperoleh tanggal 7 Januari 2014.

Setyoadi, \& Endang, T. 2012. Strategi Pelayanan Keperawatan Bagi Penderita AIDS. Yogyakarta: Graha Ilmu.

Siti,H. 2013. Hubungan Antara Pengetahuan Dengan Sikap Wanita Usia Subur Tentang Pemeriksaan Pap Smear Di RW V Desa Sulursari Kecamatan Gabus Kabupaten Grobogan. http:// perpusnwu.web.id diakses tanggal 2 januari 2014

Sugiyono. 2007. Statistikan Untuk Penelitian. Bandung: CV Alfabeta.

Sulistyawati, A. 2011. Asuhan Kebidanan pada Masa Kehamilan . Jakarta: Salemba Medika.

Ummu, A. 2009. Pencegahan Penularan HIV dari Ibu Ke Bayi: Penatalaksaan Di

Pelayanan Kebidanan. Jakarta: TIM.

UNAIDS. 2013. Report on the global AIDS epidemic. UNAIDS. Switzerland.

Wawan, \& Dewi, M. 2010. Teori \& Pengukuran Pengetahuan, Sikap dan Perilaku Manusia. Nuha Medika: Yogyakarta. 